\title{
OPTIMASI PRODUKSI SENYAWA VANILIN DARI BIOKONVERSI LIGNOSELULOSA TANDAN KOSONG KELAPA SAWIT DENGAN PHANEROCHAETE CHRYSOSPORIUM MENGGUNAKAN RESPONSE SURFACE METHOD
}

\section{Optimization Production of Vanillin Compounds from Bioconversion of Lignoselulosa Empty Fruit Palm with Phanerochaete chrysosporium Using Response Surface Method}

\author{
Rohmah, Sri Suhartini, Irnia Nurika* \\ Jurusan Teknologi Industri Pertanian - Fakultas Teknologi Pertanian -Universitas Brawijaya \\ Jl. Veteran - Malang 65145 \\ Penulis Korespondensi, email : irnia@ub.ac.id
}

Disubmit : 13 Juli $2021 \quad$ Direvisi : 26 Oktober $2021 \quad$ Diterima : 15 Desember 2021

\begin{abstract}
ABSTRAK
Limbah tandan kosong kelapa sawit (TKKS) merupakan limbah hasil produksi minyak sawit yang memiliki kandungan lignoselulosa (lignin, selulosa, hemiselulosa) tinggi, dapat dimanfaatkan untuk produksi senyawa aromatik vanilin dengan menggunakan jamur Phanerochaete chrysosporium dan pelarut etil asetat. Diketahui pelarut etil asetat dan lama ekstraksi berpengaruh terhadap kadar vanilin dan yield vanilin dengan Response Surface Methode (RSM) terdiri dari 4 faktor yang digunakan untuk mengukur sejauh mana faktor-faktor tersebut saling berpengaruh terhadap kadar vanilin. Regresi terdiri dari 13 titik faktorial dengan 6 titik aksial, dan 7 titik tengah melalui softwere Design Expert 7.0.0. Faktor-faktor optimasi digabung untuk mendapatkan nilai optimum untuk menghasilkan kadar dan yield vanilin yang bagus. Hasil penelitian optimasi RSM volume pelarut etil asetat yaitu 100,36 mL dan lama ekstraksi yaitu 120,27 menit yang digunakan dalam penelitian TKKS dengan nilai validasi optimal yang didapatkan yaitu kadar vanilin mendekati hasil prediksi sebesar $0,015 \%$ dan yield vanilin sebesar 11,862 $\mu \mathrm{g} / \mathrm{g}$. Hasil dalam penelitian ini menunjukkan penggunaan bio-pretreatment Phanaerocaete chrysosporium sebagai biokonversi TKKS menghasilkan vanilin dapat menekan biaya besar dan meningkatkan nilai fungsi dari limbah TKKS
\end{abstract}

Kata Kunci: Etil Asetat; Senyawa Aromatik; Jamur Pelapuk Putih

\begin{abstract}
Oil palm empty fruit bunches (OPEFB) waste is a waste from palm oil production which has a high content of lignocellulose (lignin, cellulose, hemicellulose), which can be used for the production of vanillin aromatic compounds using Phanerochaete chrysosporium fungus and ethyl acetate as solvent. It is known that ethyl acetate solvent and extraction time have an effect on vanillin content and vanillin yield with the Response Surface Method (RSM) consisting of 4 factors that are used to measure the extent to which these factors influence the vanillin content. Regression consists of 13 factorial points with 6 axial points, and 7 midpoints through the Design Expert 7.0.0 software. The optimization factors were combined to obtain the optimum value to produce good vanillin content and yield. The results of the optimization research RSM volume of ethyl acetate solvent that is $100.36 \mathrm{~mL}$ and extraction time of 120.27 minutes used in OPEFB research with the optimal validation value obtained, namely: vanillin content is close to the predicted result of $0.015 \%$ and vanillin yield is $11.862 \mu \mathrm{g} / \mathrm{g}$. The results in this study indicate that the use of phanaerocaete chrysosporium bio-pretreatment as an OPEFB bioconversion to produce vanillin can reduce high costs and increase the functional value of OPEFB waste
\end{abstract}

Keyword: Aromatic Compounds; Ethyl Acetate; White Rot Fungus 
Jurnal Teknologi Pertanian Vol. 22 No. 3 [Desember 2021] 201-210

Optimasi Produksi Senyawa Vanilin dari Biokonversi Lignoselulosa Tandan Kosong Kelapa Sawit [Rohmah dkk]

\section{PENDAHULUAN}

Tandan kosong kelapa sawit (TKKS) merupakan limbah yang dihasilkan dari proses pembuatan minyak kelapa sawit, yang memiliki potensi untuk dimanfaatkan sebagai bahan baku penghasil produk bernilai tambah (Chang, 2018; Ibrahim et al., 2008). TKKS seringkali dianggap sebagai salah satu limbah yang sangat sulit untuk dimanfaatkan karena strukturnya terlalu keras, berserabut dan di Indonesia sendiri belum banyak tempat pengolahan limbah TKKS secara optimal (Maitah et al., 2016). Menurut Gabungan Pengusaha Kelapa Sawit Indonesia (GAPKI), jumLah produksi kelapa sawit pada tahun 2019 sebanyak 46 juta ton, banyaknya produksi kelapa sawit mengakibatkan limbah TKKS di industri meningkat setiap tahunnya, dan diperlukan beberapa penanganan untuk mengolah limbahnya agar tidak merusak lingkungan (Jin et al., 2018; Panwar et al., 2011).

Purnamayani (2013) menyatakan bahwa jumLah TKKS setiap tahun mengalami peningkatan yaitu 6 juta ton/tahun dikarenakan jumLah konsumsi minyak kelapa dan kebutuhan pasar ekspor selalu bertambah. Produksi limbah TKKS di Indonesia bisa sampai 40 juta ton/tahun tergantung produksi yang dilakukan oleh pabrik (Rahayu et al., 2018).

Razali et al. (2012) memaparkan produksi minyak goreng dari tandan buah segar kelapa sawit akan terpecah menjadi beberapa bagian yaitu $21 \%$ minyak, inti sawit $7 \%$, serat mesocarp 14\%, kulit inti sawit 7\%, dan tandan kosong kelapa sawit $23 \%$. Limbah TKKS terdiri dari 30,5\% selulosa, 19,5 hemiselulosa, dan 32,17\% lignin (Medina et al., 2015; Hosseini dan Wahid, 2014; Suksong et al., 2019; Torres et al., 2021).

Metode pretreatment secara biologi dapat digunakan untuk memanfaatkan limbah TKKS untuk menghasilkan produk bernilai tambah, salah satunya dengan menggunakan jamur pelapuk putih Phanerochaete chrysosporium yang memiliki kemampuan degradasi lignin dan memiliki efektifitas stinggi dalam proses degradasi lignoselulosa (Sharma et al., 2021; Couto et al., 2006). Penggunaan biotreatment penggunaan enzim untuk mendegradasi struktur lignoselulosa pada TKKS dinilai lebih efektif, hasil baik, dan tidak menyebabkan toksik terhadap lingkungan (Piñeros-castro dan Velásquez-lozano, 2014).
Phanerochaete chrysosporium bekerja secara efektif memecah struktur lignoselulosa dengan enzim ekstraseluler yang meliputi manganase peroksidase (mnp), lignin peroksidase (lip) dan laccase (lac), feruloyl dan p-coumaroyl esterase (Piñeros-castro dan Velásquez-lozano, 2014; Zeng et al., 2010). Hal ini juga dipaparkan oleh Kwong (2009), jika jamur pelapuk putih Phanerochaete chrysosporium memiliki berbagai kombinasi enzim untuk mendegradasi yaitu laccase, lingnin peroksidase (LiP), dan manganase peroxidase (MnP).

Phanerochaete chrysosporium diharapkan dapat memberikan nilai tambah dengan menghasilkan produk bernilai tambah, yaitu senyawa vanilin dari TKKS melalui proses delignifikasi (Fache et al., 2015). Vanilin adalah senyawa alami vanila yang digunakan dalam makanan selama berabad-abad tahun, dan merupakan bahan kaya akan fitokimia atau senyawa perasa, yang sulit untuk dipisahkan karena struktur kimianya terutama polimer pektin yang menyebabkan ekstraksi vanilin menjadi sangat sulit (Doble dan Kruthiventi, 2007; Hocking, 1997; Zhang et al., 2014).

Vanilin diproduksi dari tanaman vanila yang masih dianggap belum memenuhi kebutuhan pasar dikarenakan keberadaan biji vanila terjangkau. Perusahaan terkenal prancis memperoduksi vanilin melalui senyawa asam ferulik dengan harga kisaran USD $700 / \mathrm{kg}$, harga bisa mencapai kisaran USD 1.800/kg jika vanilin berasal dari biji vanila, sedangkan untuk sintesis vanilin seharga USD 15/ kg (Martău et al., 2021). Saat ini, vanilin sudah diproduksi dalam skala industri dengan jumLah 20.000 ton per tahun dan 15\% bahan baku yang digunakan berasal dari lignin (3.000 ton/tahun) (Holladay et al., 2007; Jadhav et al., 2009). Ekstraksi vanilin dengan pelarut organik etil asetat dianggap sangat baik, untuk mengekstrak senyawa vanilin dikarenakan senyawa semi polarnya yang dapat mengikat senyawa spesifik aromatik termasuk vanilin dari komponen fenolik (Popescu et al., 2020)

Oleh karena itu, penelitian kali ini bertujuan untuk mengukur pengaruh biopretreatment menggunakan Phanerochaete crysosporium dalam mendegradasi biomassa lignoselulosa TKKS untuk menghasilkan senyawa vanilin yang kemudian pada tahap pengolahan data menggunakan RSM untuk mendapatkan nilai validasi. Variabel respon yang digunakan dalam penelitian kali ini yaitu (kadar vanilin dan yield vanilin) yang dipengaruhi oleh beberapa variabel 
independennya (volume pelarut etil asetat dan lama ekstraksi) (Abdulgader et al., 2018).

\section{METODE}

Bahan baku yang digunakan dalam penelitian ini adalah tandan kosong kelapa sawit yang diperoleh dari pabrik pengolahan kelapa sawit Blitar PT. Sawit Arummadani. Fungi yang digunakan adalah Phanerochaete Chrysosporium diperoleh dari Laboratorium Bioindsutri Teknologi Industri Pertanian Universitas Brawijaya Malang. Media komersial yang digunakan adalah malt extract agar (MEA), barley, aquades, kalsium karbonat $\left(\mathrm{CaCO}_{3}\right)$, etil asetat, alkohol 70\%, spirtus, 3,5 Dinitrosalysilic acid (DNS) (Nurika et al., 2020). Alat yang digunakan pada tahapan penelitian ini autoklaf, laminar air flow, inkubator, oven listrik, spektrofotometer UV-Vis, sentrifuse, magnet stirrer, dan shaker waterbath.

\section{Responce Surface Methode (RSM)}

Optimasi diterapkan pada faktor volume pelarut dan lama ekstraksi dengan metode Responce Surface Methodology (RSM) untuk mendapatkan kondisi optimal vanilin dari biomass TKKS. Taraf level untuk masing-masing faktor dapat dilihat pada Tabel 1. Pembagian faktor antara lain volume pelarut dan lama esktraksi (variabel bebas) (Lun et al., 2014; Nassiri Mahallati, 2020). Variabel respon yang diterapkan adalah kadar vanilin $(\%)$ dan yield vanilin $(\mu \mathrm{g} / \mathrm{g})$ pada respon kadar satuan vanilin yang digunakan berdasarkan berat $(\mathrm{g})$ sampel hasil ekstraksi etil asetat dapat dilihat pada Tabel 2.

Berdasarkan Tabel 1, dapat dilihat jarak antara level yaitu:

1. Jarak antara faktor volume pelarut $=100-80=$ $20 \mathrm{~mL}$

2. Jarak antara level faktor lama ekstraksi $=120$ $60=60$ menit.

Tabel 1. Taraf level faktor

\begin{tabular}{lccc}
\hline & \multicolumn{3}{c}{ Level faktor } \\
\hline & -1 & 0 & 1 \\
\cline { 2 - 4 } Volume pelarut (mL) & 80 & 100 & 120 \\
Lama ekstraksi (menit) & 60 & 120 & 180
\end{tabular}

*Taraf level faktor untuk menentukan level faktor terendah dan tertinggi

Menurut Rangkuti et al. (2018), penetapan untuk mengetahui level tertinggi dan terendah dari masing-masing faktor. Level-level faktor yang sesuai dengan titik pusat $X_{1}=0$ dan $X_{2}=0$.
Untuk faktor volume pelarut (A) dan lama esktraksi (B) dapat dinyatakan variabelnya pada persamaan (1) dan (2):

$$
\begin{aligned}
& X_{1}=\frac{\mathrm{A}-(100)}{20}, \mathrm{~A} 20 \mathrm{X} 1+100 \ldots \ldots \ldots \\
& X_{2}=\frac{\mathrm{A}-(100)}{60}, \mathrm{~B} 60 \mathrm{X} 1+120 \ldots \ldots \ldots \ldots
\end{aligned}
$$

Nilai star point (a) didapatkan dari perhitungan $\alpha=2^{\mathrm{k} / 4}$, karena penelitian ini menggunakan 2 faktor maka nilai $\mathrm{k}=2$, sehingga nilai $\alpha=2^{2 / 4}=1,414$. Selanjutnya, nilai $\alpha$ tersebut disesuaikan dengan level faktor yang telah di tetapkan yaitu $-\alpha=-1,414$ dan $\alpha=1,414$. Selanjutnya nilai A dan B untuk masing-masing level faktor (a dan a) dapat diketahui menggunakan Persamaan (i) sehingga didapatkan nilai Persamaan (i) berikut ini.

$$
\begin{aligned}
\text { a. } X 1=-1,414 \text {; sehingga nilai } A=20(-1.414)+ \\
\\
\text { b. } \mathrm{X} 1=00=71,72 \mathrm{~mL} \\
\quad 100=128,28 \mathrm{~mL}
\end{aligned}
$$

Persamaan (ii):

a. $\mathrm{X} 2=-1,414$; sehingga nilai $B=60(-1,414)+120$

$$
=35,16 \text { menit }
$$

b. $\mathrm{X} 2=1,414$; sehingga nilai $\mathrm{B}=60(1.414)+20=$ 204,84 menit.

Berdasarkan rancangan percobaan yang diperoleh, maka didapatkan titik komposit terpusat pada Tabel 3 .

\section{HASIL DAN PEMBAHASAN}

Optimasi Kadar Senyawa Vanilin dari Degradasi TKKS dengan $P$. chrysosporium

Model regresi variabel respon yang digunakan dalam penelitian ini adalah kadar dan yield vanilin, sedangkan untuk variabel independen berupa lama ekstraksi dan volume pelarut etil asetat. Regresi terdiri dari 13 titik faktorial dengan 6 titik aksial dan 7 titik tengah. Kadar vanilin tertinggi sebesar $0,0163 \%$ pada lama ekstraksi 120 menit dengan $100 \mathrm{~mL}$ etil asetat dan memiliki nilai terkecil $0,0006 \%$ pada lama ektraksi 60 menit dan volume pelarut etil asetat sebanyak $80 \mathrm{~mL}$, sedangkan untuk yield vanilin nilai tertinggi sebesar $11.0653 \mu \mathrm{g} / \mathrm{g}$ pada volume pelarut $100 \mathrm{~mL}$ dan lama ekstraksi 120 menit dan memiliki nilai terkecil $0,0234 \mu \mathrm{g} / \mathrm{g}$ pada volume pelarut sebesar $80 \mathrm{~mL}$ dan lama ekstraksi 60 menit yang dapat dilihat pada Gambar 1 dan 2. 
Jurnal Teknologi Pertanian Vol. 22 No. 3 [Desember 2021] 201-210

Optimasi Produksi Senyawa Vanilin dari Biokonversi Lignoselulosa Tandan Kosong Kelapa Sawit [Rohmah dkk]

Tabel 2. Rancangan percobaan (Design expert 7)

\begin{tabular}{ccccccc}
\hline & \multicolumn{2}{c}{ Variabel kode } & \multicolumn{2}{c}{ Variabel Asli } & \multicolumn{2}{c}{ Respon } \\
\cline { 2 - 7 } & $\mathrm{X}_{1}$ & $\mathrm{X}_{2}$ & $\begin{array}{c}\text { Volume } \\
\text { Pelarut }(\mathrm{mL})\end{array}$ & $\begin{array}{c}\text { Lama Ekstraksi } \\
(\mathrm{menit})\end{array}$ & $\begin{array}{c}\text { Kadar vanilin } \\
(\%)\end{array}$ & $\begin{array}{c}\text { Yield vanilin } \\
(\mu \mathrm{g} / \mathrm{g})\end{array}$ \\
\hline 1 & 1 & -1 & 120 & 60 & $\mathrm{Y} 1$ & $\mathrm{Y} 2$ \\
2 & 0 & 0 & 100 & 120 & $\mathrm{Y} 1$ & $\mathrm{Y} 2$ \\
3 & 1,414 & 0 & 128,28 & 120 & $\mathrm{Y} 1$ & $\mathrm{Y} 2$ \\
4 & 0 & 1,414 & 100 & 204,85 & $\mathrm{Y} 1$ & $\mathrm{Y} 2$ \\
5 & 0 & $-1,414$ & 100 & 35,15 & $\mathrm{Y} 1$ & $\mathrm{Y} 2$ \\
6 & 0 & 0 & 100 & 120 & $\mathrm{Y} 1$ & $\mathrm{Y} 2$ \\
7 & 1 & 1 & 120 & 180 & $\mathrm{Y} 1$ & $\mathrm{Y} 2$ \\
8 & 0 & 0 & 100 & 120 & $\mathrm{Y} 1$ & $\mathrm{Y} 2$ \\
9 & 0 & 0 & 100 & 120 & $\mathrm{Y} 1$ & $\mathrm{Y} 2$ \\
10 & $-1,414$ & 0 & 71,72 & 120 & $\mathrm{Y} 1$ & $\mathrm{Y} 2$ \\
11 & 0 & 0 & 100 & 120 & $\mathrm{Y} 1$ & $\mathrm{Y} 2$ \\
12 & -1 & 1 & 80 & 180 & $\mathrm{Y} 1$ & $\mathrm{Y} 1$ \\
13 & -1 & -1 & 80 & 60 & & \\
\hline
\end{tabular}

Tabel 3. Titik komposit terpusat yang dicobakan

\begin{tabular}{lccccc}
\hline Faktor & $-a$ & -1 & 0 & 1 & $+a$ \\
\hline Volume Pelarut $(\mathrm{mL})$ & 71,72 & 80 & 100 & 120 & 128,28 \\
Lama Ekstraksi (menit) & 35,16 & 60 & 120 & 180 & 204,84 \\
\hline
\end{tabular}

Hasil analisis ragam ANOVA menunjukkan respon kadar vanilin dengan model quadratic, memiliki nilai $p$ model sebesar 0,0001 $(p<0,05)$ menunjukkan model signifikan. Hasil ANOVA untuk faktor volume etil asetat dan lama ekstraksi diperoleh nilai signifikansi $(p<0,05)$ menunjukkan faktor volume pelarut etil asetat dan lama ekstraksi berpengaruh secara signifikan terhadap kadar vanilin (Bahadar et al., 2015; Czemplik et al., 2017). Nilai $p$ kurang dari 0,05 didapatkan pada $\mathrm{A}^{2}$ dan $\mathrm{B}^{2}$ yang menunjukkan volume etil asetat kuadrat $\left(\mathrm{A}^{2}\right)$ dan lama ekstraksi kuadrat $\left(\mathrm{B}^{2}\right)$ berpengaruh secara signifikan (Gunawan dan Suhendra, 2010). Hasil menunjukkan faktor interaksi antara volume etil asetat dan lama ekstraksi secara quadratic berpengaruh nyata terhadap kadar vanilin TKKS dengan p-value 0,0001 $(p<0,05)$. Hal ini diperkuat oleh penelitian dari Cicchetti dan Chaintreau (2009) yang menjelaskan bahwa dengan menggunakan pelarut etil asetat dapat menghasilkan $84 \%$ ekstrak vanilin daripada pelarut lainnya (etahnol, methanol, methylene chloride, dan pentane) dari biji kedelai madagaskar.

Nilai lack of fit (ketidaksesuaian) pada respon kadar vanilin memiliki nilai $p$ sebesar $0,0016(p<0,05)$ dengan keterangan tidak signifikan. Pada data fit summary kadar vanilin menunjukkan penggunaan model yang di anjurkan merupakan model quadratic dikarenakan model signifikan $(p<0,05)$ dengan nilai $p$ sebesar 0,0001, memiliki keterangan "aliased" yang artinya tidak semua parameter model kubik bisa diperkirakan secara spesifik (Fathur et al., 2018; Myers et al., 2009). Pemilihan model juga berdasarkan nilai $\mathrm{R}^{2}$ dari model quadratic sebesar 0,9523 tertinggi dibandingkan dengan model lainnya sehingga model terpilih adalah model quadratic.

Pemilihan model juga didasarkan pada hasil model summary statistik dimana model yang dipilih adalah model dengan nilai adjusted $\mathrm{R}^{2}$ dan predicted $\mathrm{R}^{2}$ yang maksimal, dengan nilai $\mathrm{R}^{2}$ yang didapat sebesar 0,9523 , maka dari pernyataan tersebut bisa dikatakan model terbaik adalah model quadratic (Rangkuti et al., 2018). Hasil tersebut menunjukkan model quadratic yang digunakan sudah sangat cocok dan dapat digunakan sebagai prediksi. Warna pada kontur mengalami peningkatan yaitu semakin merah yang artinya kadar vanilin semakin tinggi dapat dilihat pada Gambar 1. 


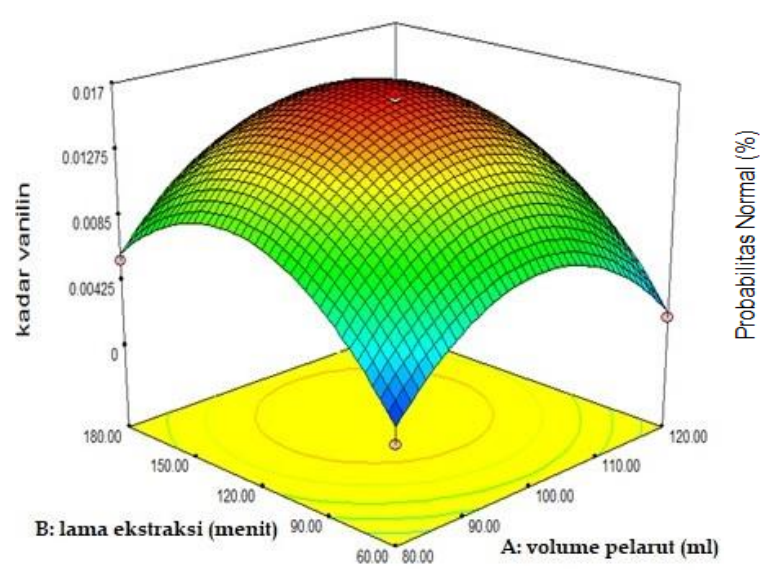

(a)

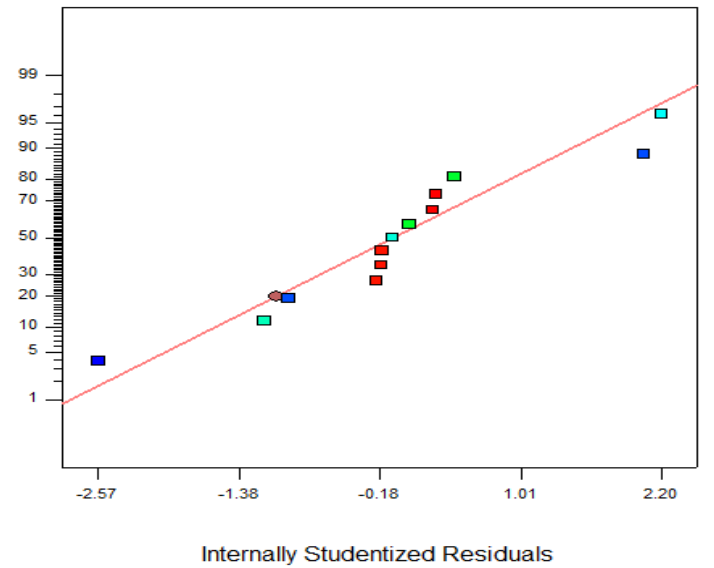

(b)

Gambar 1. Kontur kadar vanilin (3D) (a) plot kontur yang menunjukkan pengaruh lama ekstraksi (menit) dan volume pelarut $(\mathrm{mL})$ terhadap kadar vanilin $(\%)(b)$ titik persebaran probabilitas normal kadar vanilin TKKS setelah dilakukan pretreatment menggunakan $P$. chrysosporium

Kenaikan kadar vanilin terjadi seiring bertambahnya lama ekstraksi yang dilakukan disebabkan jumLah kandungan fenolik pada bahan yang diekstrak dan ekstraksi senyawa fenol seperti vanilin dipengaruhi oleh beberapa parameter pada proses ekstraksi seperti volume pelarut, temperatur, suhu dan lama waktu ekstraksi (Auras, 2007; Spigno et al., 2007; Dewi dan Gapsari, 2013).

Persamaan polinomial/matematika yang digunakan untuk mengetahui hasil nilai quadratic dari kadar vanilin dapat dilihat pada Persamaan (3).

$\mathrm{Y}_{2}=0,016+4,964\left(\mathrm{X}_{1}\right)+2,442\left(\mathrm{X}_{2}\right)+2,304\left(\mathrm{X}_{1} \mathrm{X}_{2}\right)$ $-5,861\left(X_{1}^{2}\right)-5,874\left(X_{2}^{2}\right)$

dimana :

$\mathrm{Y}_{2}=$ Variabel respon kadar vanillin

$\mathrm{X}_{1}=$ Faktor volume etil asetat

$\mathrm{X}_{2}=$ Faktor lama ekstraksi

Menurut Dewi et al. (2019), koefisien positif yang dihasilkan menunjukkan terdapat hubungan berbanding lurus, atau artinya semakin tinggi $X_{1}, X_{2}$ dan interaksi keduanya maka akan semakin tinggi kadar vanilin. Namun apabila koefisien negatif, berarti terdapat hubungan berbanding terbalik, atau artinya semakin tinggi nilai kuadrat dari $\mathrm{X}_{1}$ dan $X_{2}$ maka semakin rendah kadar vanilin yang dihasilkan dari TKKS.

Model quadratic menunjukkan bahwa respon kadar vanilin dipengaruhi oleh lama ekstraksi dan volume pelarut etil asetat.
Pengaruh yang diberikan kadar vanilin lebih dominan pada respon volume pelarut dibandingkan dengan lama ekstraksi. Hal ini dapat dilihat dari koefisien $\mathrm{X}_{1}$ memiliki nilai yang lebih besar yaitu 4,96 jika dibandingkan $\mathrm{X}_{2}$ lama ekstraksi 2,44. Persamaan (3) juga menggambarkan bahwa lama ekstraksi dan volume pelarut yang memberikan pengaruh berbanding terbalik terhadap respon. Hal ini ditujukan oleh nilai negatif (-) konstanta (Syahrul et al., 2017).

Optimasi yield Senyawa Vanilin dari Degradasi TKKS dengan $P$. chrysosporium

Berdasarkan rancangan percobaan menggunakan RSM, diperoleh hasil data respon yield vanilin dari kombinasi perlakuan volume pelarut etil asetat dan lama ekstraksi. Berdasarkan penelitian yang dilakukan, yield vanilin tertinggi diperoleh sebesar 11,0653 $\mu \mathrm{g} / \mathrm{g}$ dan nilai terkecil sebesar $0,0234 \mu \mathrm{g} / \mathrm{g}$ pada lama ekstraksi 120 menit dan volume pelarut $100 \mathrm{~mL}$ yang daat dilihat pada Gambar 2. Hasil data fit summary menunjukkan penggunaan model yang disarankan adalah model quadratic dikarenakan model tersebut model signifikan $(p<0,05)$ dengan nilai $p$ sebesar 0,0001 (Nurmiah et al., 2013). Pemilihan model juga berdasarkan pada nilai $\mathrm{R}^{2}$ dari model quadratic sebesar 0,9245 tertinggi dibandingkan dengan model lainnya sehingga model yang dipilih adalah model quadratic. 

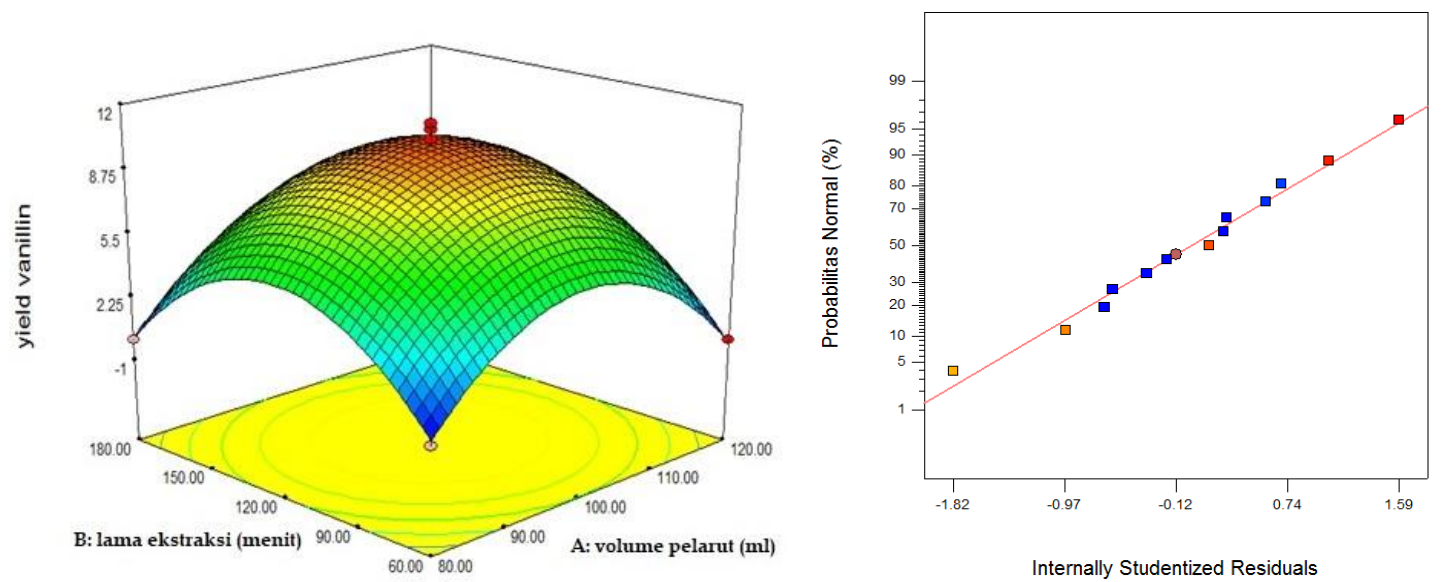

Gambar 2. Kontur yield vanilin (3D) dan (a) plot kontur yang menunjukkan pengaruh lama ekstraksi (menit) dan volume pelarut $(\mathrm{mL})$ terhadap yield vanilin $(\mu \mathrm{g} / \mathrm{g})(\mathrm{b})$ titik persebaran probabilitas normal yield vanilin TKKS setelah dilakukan pretreatment menggunakan P. chrysosporium

Pada pemilihan model kubik terdapat penjelasan "aliased" karena model terlalu kompleks dan tidak didukung oleh desain komposit terpusat sehingga model kubik tidak disarankan meskipun memiliki nilai $p<0,05$. pemilihan model, yang dipilih adalah model dengan nilai $\mathrm{R}^{2}$ dan predicted $\mathrm{R}^{2}$ yang maksimal dan yang di sarankan oleh model adalah model quadratic daripada model kubik.

Kenaikan yield vanilin pada jumLah pelarut tertinggi menunjukkan semakin banyak pelarut etil asetat yang digunakan maka semakin tinggi nilai yield vanilin yang dihasilkan dan berpengaruh secara signifikan dalam hasil vanilin yang didapat yaitu sebesar $21,3 \mathrm{mg} / \mathrm{g}$ (Do et al., 2013). Popescu et al. (2020) juga memaparkan pelarut etil asetat sangat baik digunakan sebagai pengikat senyawa aromatik vanilin dari kraft lignin dan baik dalam segala aspek (polusi, ketersediaan, dan harga) dibandingan dengan pelarut lain. Pelarut etil asetat memiliki sifat semi polar yang dapat mengikat senyawa organik flavonoid lainnya secara efektif (Aji, 2019).

Hasil ANOVA untuk respon yield vanilin dengan model quadratic dimana nilai $p$ dari model sebesar sebesar 0,0001 $(p<0,05)$ yang menunjukkan model signifikan (MuñizMárquez et al., 2019). Hasil ANOVA untuk faktor volume pelarut etil asetat dan lama ekstraksi, interaksi kedua faktor tersbut memiliki nilai signifikansi $(p<0,05)$ yang menujukkan faktor volume pelarut etil asetat dan lama ekstraksi berpengaruh secara signifikan terhadap yield vanilin. Memiliki nilai $p$-value sebesar $0,9245(p>0,05)$ dengan keterangan yang mengindikasikan bahwa model dapat mendeskripsikan data respon yield vanilin sehingga dapat disimpulkan bahwa model yang didapat cocok digunakan untuk memprediksi kondisi proses ekstraksi yang menghasilkan yield vanilin yang optimum. Hasil tersebut menunjukkan model quadratic yang digunakan sudah cocok dan dapat digunakan sebagai prediksi. Memiliki nilai $\mathrm{R}^{2}$ sebesar 0,9910 atau $99,10 \%$ pada model quadratic sehingga model yang dipilih adalah quadratic. Probabilitas normal yield vanilin menunjukkan persebaran titik data tidak memiliki titik persebaran yang jauh sehingga bisa dikatakan data yang dihasilkan masih normal yang dapat dilihat pada Gambar 2 (Sarabia dan Ortiz, 2009). Persamaan (4) merupakan persamaan polinomial yang digunakan untuk mengetahui model quadratic yang dihasilkan.

$Y_{1}=10,27-2,113\left(X_{1}\right)+0,095\left(X_{2}\right)+0,17\left(X_{1} X_{2}\right)-$ $4,94\left(\mathrm{X}_{1}^{2}\right)-5,05\left(\mathrm{X}_{2}^{2}\right)$

dimana :

$\mathrm{Y}_{1}=$ Variabel respon yield vanillin

$\mathrm{X}_{1}=$ Faktor volume etil asetat

$\mathrm{X}_{2}=$ Faktor lama ekstraksi

Koefisien positif dari yield vanilin menunjukkan hubungan yang berbanding lurus atau artinya semakin tinggi $\mathrm{X}_{1}, \mathrm{X}_{2}$, dan interaksi keduanya maka akan semakin tinggi yield vanilin. Jika koefisien negatif berarti terdapat hubungan berbanding terbalik, yang artinya semua nilai kuadrat dari $X_{1}$ dan $X_{2}$ maka akan semakin rendah yield vanilin yang dihasilkan dari sampel TKKS (Dewi et al., 2019). 
Model quadratic menujukkan yield vanilin lebih dominan pada respon volume pelarut dibandingkan dengan lama ekstraksi. Hal ini dapat dilihat dari koefisien $\mathrm{X}_{1}$ memiliki nilai yang lebih besar yaitu 2,11 jika dibandingkan dengan $\mathrm{X}_{2}$ lama ekstraksi 0,09. Persamaan (4) juga menggambarkan bahwa lama ekstraksi dan volume pelarut yang memberikan pengaruh berbanding terbalik terhadap respon, hal ini ditujukan oleh nilai negatif (-) konstanta (Syahrul et al., 2017).

\section{Nilai Optimal dan Validasi dari Faktor-Faktor}

Hasil validasi menggunakan nilai solusi optimasi yang diperoleh dari RSM yang bisa dilihat pada Tabel 4, dimana volume pelarut sebesar 100,36 mL, lama ekstraksi sebesar 125,27 menit, dan ketepatan atau desirability sebesar 0,957 yang menandakan jika nilai desirablity mendekati 1 menunjukkan bahwa tujuan/goal telah terpenuhi (Fathur et al., 2018). Hasil validasi nilai optimum pada Tabel 5 didapat hasil validasi dengan volume pelarut etil asetat sebesar 100,36 mL dan lama ekstraksi sebesar 125,27 menit. Diketahui dari hasil validasi di dapat kadar vanilin 0,015 atau $1,5 \%$ dengan yield vanilin $10,513 \mu \mathrm{g} / \mathrm{g}$, maka bisa disimpulkan kadar vanilin telah mendekati angka solusi yaitu 0,016 dan yield vanilin sebesar 10,137 $\mu \mathrm{g} / \mathrm{g}$. Data tersebut menunjukkan nilai volume pelarut dan lama ekstraksi sangat berpengaruh terhadap kadar dan yield vanilin, etil asetat sebagai pelarut dikatakan sangat efektif dalam melarutkan senyawa organik dalam suatu bahan karena sifatnya yang semi polar memudahkanya dalam pengikatan senyawa organik dalam suatu zat (Sánchez-Camargo et al., 2019; Pintać et al., 2018; Ramić et al., 2015). Spigno et al. (2007) dalam penelitiannya memaparkan lama ekstraksi yang digunakan pada ekstraksi menggunakan pelarut etil asetat adalah 1-12 jam untuk menghasilkan yield proanthocyanidins, dan tergantung jenis bahan yang digunakan.

\section{SIMPULAN}

Degradasi senyawa lignoselulosa dengan P. chrysosporium sangat efektif dalam produksi senyawa vanilin dari biomasa TKKS, dan volume pelarut etil asetat serta lama esktraksi berpengaruh nyata terhadap kadar dan yield vanilin. Etil asetat memiliki kemampuan mengikat senyawa organik fenolik (vanilin) dalam biomas tandan kosong kelapa sawit karena sifatnya semi polar cocok dengan karakteristik senyawa organik pada tumubhan khususnya fenolik. Hasil dari RSM menunjukkan solusi optimal lama ekstraksi dan volume pelarut untuk mendapatkan kadar dan yield vanilin tinggi yaitu: volume pelarut sebesar 100,36 $\mathrm{mL}$ dengan lama ekstraksi 120,27 menit yang menghasilkan rendemen kadar vanilin rata-rata $0,015 \%$ dan yield vanilin sebesar 11,862 $\mu \mathrm{g} / \mathrm{g}$.

Tabel 4. Solusi optimal berdasarkan RSM

\begin{tabular}{|l|l|c|}
\hline Kriteria & Parameter & Standar prediksi \\
\hline Faktor & Volume pelarut etil asetat $(\mathrm{mL})$ & 100,36 \\
\hline Faktor & Lama ekstraksi (menit) & 125,27 \\
\hline Respon & Kadar vanilin $(\%)$ & 0,016 \\
\hline Respon & Yield vanilin $(\mu \mathrm{g} / \mathrm{g})$ & 10,13 \\
\hline Ketepatan (desirability) & - & 0,957 \\
\hline Keterangan & - & Dipilih \\
\hline
\end{tabular}

Tabel 5. Hasil validasi TKKS menggunakan nilai prediksi faktor volume etil $(\mathrm{mL})$ asetat dan lama ekstraksi (menit)

\begin{tabular}{|l|c|c|c|c|}
\hline Sampel & Volume pelarut & Lama ekstraksi & Kadar vanilin & Yield vanilin $(\boldsymbol{\mu g} / \mathbf{g})$ \\
\hline R1 & 100,36 & 125,27 & 0,014 & 10,513 \\
\hline R2 & 100,36 & 125,27 & 0,015 & 11,862 \\
\hline
\end{tabular}

${ }^{*}$ R1\&R2 merupakan jenis sampel TKKS yang dilakukan uji menggunakan data prediksi RSM 
Jurnal Teknologi Pertanian Vol. 22 No. 3 [Desember 2021] 201-210

Optimasi Produksi Senyawa Vanilin dari Biokonversi Lignoselulosa Tandan Kosong Kelapa Sawit [Rohmah dkk]

\section{DAFTAR PUSTAKA}

Abdulgader, -M., Yu, -J., Zinatizadeh, A, -A., Williams, -P., Rahimi, -Z., 2018. Process analysis and optimization of single stage flexible fibre biofilm reactor treating milk processing industrial wastewater using response surface methodology (RSM). Chemical Engineering Research and Design. 149, 169-181. https://doi.org/10.1016/j.cherd.2019.07.011

Aji, -N., 2019. Pengaruh pelarut campur etil asetat dan n-heksan terhadap rendemen dan kandungan metabolit sekunder ekstrak daun bidara arab (Ziziphus sphina-christi L). Pharmacoscript. 2(2), 1-8. https://doi.org/10.36423/pharmacoscri pt.v2i1.222

Auras, R. 2007. 'Solubility of Gases and Vapors in Polylactide Polymers'. Dalam Letcher TM. (Ed.), Thermodynamics, Solubility and Environmental Issues. Elsevier BV, Amsterdam

Bahadar, A., Khan, MB., Asim, MA., Jalwana, K. 2015. 'Supercritical Fluid Extraction of Microalgae (Chlorella vulagaris) Biomass'. Dalam Kim SK. (Ed.), Handbook of Marine Microalgae: Biotechnology Advances. Academic Press, Cambridge, USA

Chang, S, -H., 2018. Biomass and Bioenergy bio-oil derived from palm empty fruit bunches: Fast pyrolysis, liquefaction and future prospects. Biomass and Bioenergy. 119, 263-276. https://doi.org/10.1016/j.biombioe.2018.09.033

Cicchetti, -E., Chaintreau, -A., 2009. Comparison of extraction techniques and modeling of accelerated solvent extraction for the authentication of natural vanilla flavors. Journal of Separation Science. 32(11), 1957-1964. https://doi.org/10.1002/jssc.200800650

Couto, S, -R., Moldes, -D., Sanromán, M, -A., 2006. Optimum stability conditions of $\mathrm{pH}$ and temperature for ligninase and manganesedependent peroxidase from Phanerochaete chrysosporium. Application to in vitro decolorization of Poly R-478 by MnP. World Journal of Microbiology and Biotechnology. 22, 607-608. https://doi.org/10.1007/s11274-005$9078-0$

Czemplik, -M., Korzun-Chłopicka, -U., Szatkowski, M., Działo, -M., Szopa, -J., Kulma, -A., 2017. Optimization of phenolic compounds extraction from flax shives and their effect on human fibroblasts. Evidence-Based Complementary Alternative Medicine. 2017, 1-15. https://doi.org/10.1155/2017/3526392
Dewi, F, G, -U., Gapsari, -F., 2013. Optimasi parameter pembubutan terhadap kekasaran permukaan produk. Rekayasa Mesin. 4(3), 177-181

Dewi, I, -A., Ihwah, -A., Setyawan, H, -Y., Kurniasari, A, A, -N., Ulfah, -A., 2019. Optimasi proses delignifikasi pelepah pisang untuk bahan baku pembuatan kertas seni. SEBATIK. 23(2), 447-454. https://doi.org/10.46984/sebatik.v23i2.797

Do, Q, -D., Angkawijaya, A, -E., Tran-nguyen, P, -L., Huynh, L, -H., Soetaredjo, F, -A., Ismadji, -S., 2013. Effect of extraction solvent on total phenol content, total flavonoid content, and antioxidant activity of Limnophila aromatica. Journal of Food and Drug Analysis. 22(3), 296-302. https://doi.org/10.1016/j.jfda.2013.11.001

Doble, M., Kruthiventi, AK. 2007. 'Industrial Examples'. Dalam Green Chemistry and Engineering. Elsevier Science Publishing Co Inc, Oxford

Fache, -M., Boutevin, -B., Caillol, -S., 2015. Vanillin production from lignin and its use as a renewable chemical vanillin production from lignin and its use as a renewable chemical. ACS Sustainable Chemistry \& Engineering. 4(1), 35-46. https://doi.org/10.1021/acssuschemeng $.5 \mathrm{~b} 01344$

Fathur, A, -R., Hendrawan, -Y., Dewi, S, -R., 2018. Optimasi nilai rendemen dalam pembuatan virgin coconut oil (VCO) menggunakan pemanasan suhu rendah dan kecepatan sentrifugasi dengan response surface methodology (RSM). Jurnal Keteknikan Pertanian Tropis dan Biosistem. 6(3), 218-228

Gunawan, E, -R., Suhendra, -D., 2010. Fourfactor response surface optimization of the enzymatic synthesis of wax ester from palm kernel oil. Indonesia Journal of Chemistry. 8(1), 83-90. https://doi.org/10.22146/ijc.21653

Hocking, M, -B., 1997. Vanillin: Synthetic flavoring from spent sulfite liquor. Journal of Chemical Education. 74(9), 1055-1059. https://doi.org/10.1021/ed074p1055

Holladay, JE., White, JF., Bozell, JJ., Johnson, D. 2007. Top Value-Added Chemicals from Biomass Volume II-Results of Screening for Potential Candidates from Biorefinery Lignin. Pacific Northwest National Laboratory, USA 
Hosseini, S, -E., Wahid, M, -A., 2014. Utilization of palm solid residue as a source of renewable and sustainable energy in Malaysia. Renewable Sustainable Energy Reviews. 40, 621-632. https://doi.org/10.1016/j.rser.2014.07.214

Ibrahim, M, N, -M., Nadiah, M, Y, -N., Norliyana, M, -S., Sipaut, C, -S., Shuib, S., 2008. Separation of vanillin from oil palm empty fruit bunch lignin. Clean Soil, Air, Water. 36, 287-291. https://doi.org/10.1002/clen.200700141

Jadhav, -D., Rekha, B, -N., Gogate, P, -R., Rathod, V, K., 2009. Extraction of vanillin from vanilla pods: A comparison study of conventional soxhlet and ultrasound assisted extraction. Jurnal of Food Engineering. 93, 421-426. https://doi.org/10.1016/j.jfoodeng.2009.02.007

Jin, -Q., Yang, -L., Poe, -N., Huang, -H., 2018. Integrated processing of plant-derived waste to produce value-added products based on the biorefinery concept. Trends Food Science \& Technology. 74, 119-131. https://doi.org/10.1016/j.tifs.2018.02.014

Kwong, ST. 2009. Biodegradation of lignin in oil palm empty fruit bunch (Efb) using ligninolytic fungi. Universitas Malaysia Serawak, Malaysia

Lun, O, -K., Wai, T, -B., Ling, L, -S., 2014. Pineapple cannery waste as a potential substrate for microbial biotransformation to produce vanillic acid and vanillin. International Food Research Journal. 21(3), 953-958.

Maitah, -M., Prochazka, -P., Pachmann, -A., Šrédl, -K., Řezbová, -H., 2016. Economics of palm oil empty fruit bunches bio briquettes in Indonesia. International Journal of Energy Economics and Policy. $6(1), 35-38$

Martău, G, -A., Călinoiu, L, -F., Vodnar, D, -C., 2021. Bio-vanillin: Towards a sustainable industrial production. Trends Food Science $\mathcal{E}$ Technology. 109, 579-592. https://doi.org/10.1016/j.tifs.2021.01.059

Medina, J, D, -C., Woiciechowski, -A., Filho, A, -Z., Noseda, M, -D., Kaur, B, -S., Soccol, C, -R., 2015. Lignin preparation from oil palm empty fruit bunches by sequential acid/alkaline treatment - A biorefinery approach. Bioresource Technology. 194, 172-178. https://doi.org/10.1016/j.biortech.2015.07.018

Muñiz-Márquez, D, -B., Wong-Paz, J, -E., Contreras-Esquivel, J, -C., RodriguezHerrera, -R., Aguilar, C, -N., 2019. 'Extraction Of Phenolic Compounds From Coriandrum Sativum L. And
Amaranthus Hybridus L By Microwave Technology'. Dalam Watson, RR. (Ed.), Polyphenols in Plants. Academic Press, Cambridge, USA

Myers, RH., Montgomery, DC., AndersonCook, CM. 2009. Response Surface Methodology: Process and Product Optimization Using Designed Experiments, 4th Edition. John Wiley \& Sons, Inc., New York

Nassiri-Mahallati, M., 2020. 'Advances in Modeling Saffron Growth and Development at Different Scales'. Dalam Koocheki, A, Khajeh-Hosseini, M. (Ed.), Saffron Science, Technology and Health. Woodhead Publishing, Cambridge

Nurika, -I., Suhartini, -S., Barker, G, -C., 2020. Biotransformation of tropical lignocellulosic feedstock using the brown rot fungus serpula lacrymans. Waste and Biomass Valorization. 11, 2689-2700. https://doi.org/10.1007/s12649-01900581-5

Nurmiah, -S., Syarief, -R., Peranginangin, -R., Nurtama, -B., 2013. Aplikasi response surface methodology pada optimalisasi kondisi proses pengolahan alkali treated cottonii (ATC). Jurnal Pascapanen dan Bioteknologi Kelautan dan Perikanan. 8(1), 9-22.

Panwar, N, -L., Kaushik, S, -C., Kothari, -S., 2011. Role of renewable energy sources in environmental protection: A review. Renewable and Sustainable Energy Reviews. 15, 1513-1524. https://doi.org/10.1016/j.rser.2010.11.037

Piñeros-castro, -Y., Velásquez-lozano, -M., 2014. Biodegradation kinetics of oil palm empty fruit bunches by white rot fungi. International Biodeterioration \& Biodegradation. 91, 24-28. https://doi.org/10.1016/j.ibiod.2014.03.009

Pintać, -D., Majkić, -T., Torović, -L., Orćić, -D., Beara, -I., Mimica-dukić, -N., Lesjak, -M., 2018. Solvent selection for efficient extraction of bioactive compounds from grape pomace. Industrial Crops and Products. 111, 379-390. https://doi.org/10.1016/j.indcrop.2017.10.038

Popescu, A, E, -P., Torralba, -J., Bonet-Ruiz, -J., Llorens, -J., 2020. Solvent screening and process simulation for vanillin production from lignin. Chemical Engineering Transactions. 81, 835-840. https://doi.org/10.3303/CET2081140

Purnamayani, R. 2013. Teknologi Pembuatan Kompos Tandan Kosong Kelapa Sawit. Badan Penelitian dan Pengembangan Pertanian, Jambi 
Jurnal Teknologi Pertanian Vol. 22 No. 3 [Desember 2021] 201-210

Optimasi Produksi Senyawa Vanilin dari Biokonversi Lignoselulosa Tandan Kosong Kelapa Sawit [Rohmah dkk]

Rahayu, D, -E., Nasarani, -D., Hadi, -W., Wrjodirjo, -B., 2018. Potential of biomass residues from oil palm agroindustry in Indonesia. MATEC Web of Conferences. 197, 1-4. https://doi.org/10.1051/matecconf/20181971 3008

Ramić, -M., Vidović, -S., Zeković, -Z., Vladić, J., Cvejin, -A., Pavlić, -B., 2015. Modeling and optimization of ultrasound-assisted extraction of polyphenolic compounds from Aronia melanocarpa by-products from filter-tea factory. Ultrasonics Sonochemistry. 23, 360-368. https://doi.org/10.1016/j.ultsonch.2014.10.002

Rangkuti, E, -M., Matondang, A, -R., Matondang, -N., 2018. Aplikasi response surface methodology (RSM) untuk mempersingkat waktu pengeringan sheet di pabrik pengolahan sheet PTPN III kebun Sarang Giting. Jurnal Sistem Teknik Industri. 18(2), 61-65. https://doi.org/10.32734/jsti.v18i2.350

Razali, W, A, -W., Baharuddin, A, -S., Talib, A, -T., Sulaiman, -A., Naim, M, -N., Hassan, M, -A., Shirai, -Y., 2012. Degradation of oil palm empty fruit bunches (OPEFB) fibre during composting process using in-vessel composter. Bioresources. 7(4), 4786-4805. https://doi.org/10.15376/biores.7.4.47864805

Sánchez-Camargo, A, -P., Bueno, -M., ParadaAlfonso, -F., Cifuentes, -A., Ibáñez, -E., 2019. Hansen solubility parameters for selection of green extraction solvents. TrAC Trends in Analytical Chemistry. 118, 227-237. https://doi.org/10.1016/j.trac.2019.05.046

Sarabia, LA., Ortiz, MC. 2009. 'Response Surface Methodology'. Dalam Bown SD, Tauler, R, Walczak, B. (Ed.), Comprehensive Chemometrics Chemical and Biochemical Data Analysis. Elsevier B.V., Amsterdam

Sharma, J, -L., Dhayal, -V., Sharma, R, -K., 2021. Antibacterial effect of glycerol assisted $\mathrm{ZnO}$ nanoparticles synthesized by white rot fungus Phanerochaete chrysosporium. Materials Today Proceedings. 43, 2855-2860. https://doi.org/10.1016/j.matpr.2021.01.075

Spigno, -G., Tramelli, -L., De Faveri, D, -M., 2007. Effects of extraction time, temperature and solvent on concentration and antioxidant activity of grape marc phenolics. Journal of Food Engineering. $\quad 81(1), \quad 200-208$. https://doi.org/10.1016/j.jfoodeng.2006. 10.021

Suksong, -W., Tukanghan, -W., Promnuan, K., Kongjan, -P., Reungsang, -A., Insam, H., O-thong, -S., 2019. Biogas production from palm oil mill effluent and empty fruit bunches by coupled liquid and solid-state anaerobic digestion. Bioresource Technology. 296, 122304. https://doi.org/10.1016/j.biortech.2019. 122304

Syahrul, Syarief, -R., Hermanianto, -J., Nurtama, -B., 2017. Optimasi proses penggorengan tumpi-tumpi dari ikan bandeng used response surface methodology. Jurnal Pengolahan Hasil Perikanan Indonesia. 20(3), 432-445.

Torres L, A, -Z., Woiciechowski, A, -L., Oliveira de Andrade Tanobe, -V., Zandoná Filho, -A., Alves de Freitas, -R., Noseda, M, -D., Saito Szameitat, -E., Faulds, -C., Coutinho, -P., Bertrand, -E., Soccol, C, -R., 2021. Lignin from oil palm empty fruit bunches: Characterization, biological activities and application in green synthesis of silver nanoparticles. International Journal of Biological Macromolecules. 167, 1499-1507. https://doi.org/10.1016/j.ijbiomac.2020. 11.104

Zeng, -G., Yu, -M., Chen, -Y., Huang, -D., Zhang, -J., Huang, -H., Jiang, -R., Yu, -Z., 2010. Effects of inoculation with Phanerochaete chrysosporium at various time points on enzyme activities during agricultural waste composting. Bioresoure Technolology. 101(1), 222-227. https://doi.org/10.1016/j.biortech.2009. 08.013

Zhang, -Y., Mo, -L., Chen,- F., Lu, -M., Dong, W., Wang, -Q., Xu, -F., Gu, -F., 2014. Optimized production of vanillin from green vanilla pods by enzyme-assisted extraction combined with pre-freezing and thawing. Molecules. 19(2), 2181-2198. https://doi.org/10.3390/molecules19022 181 